\title{
Integration Of SAP Technology In Finance Classrooms: Perceptions From Students And Implications For Educators
}

Christine Hsu, (E-mail:CHsu@csuchico.edu), California State University, Chico

\begin{abstract}
To better prepare students for this highly competitive technology-rich business world, it is vital that business educators take responsibility for the development of students' information technology skills in conjunction with the conventional discipline-specific knowledge and lifelong learning skills. This study focuses on the use of one technology tool, the SAP R/3 system, in finance classrooms. The main purpose of this research is to investigate whether implementing SAP technology in the classroom enhances the student's educational experience. Students' reactions to the use of this business technology in the classroom and their implications for business educators are addressed. The findings of this study should be useful to business educators who use, or intend to use, this educational tool in their classes.
\end{abstract}

\section{Introduction}

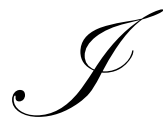

$\mathrm{n}$ recent years the impact of information technology has changed significantly the context within which the business professionals work. Numerous studies suggest that business education needs to be more effective and relevant so as to produce competent workforce for today's economy (Baker 1999, Pendegraft 1999, Paul 2001, Selen 2001, Ueltschy 2001, McCorkle 2001, Shoemaker 2003, among others). The gap between financial education and corporate business is well identified by business executives. For example, Baker and Phillips (1999) surveyed more than 200 finance executives regarding their perceptions about the gaps between what business schools teach and what companies need for entry-level finance positions and reported that "an overwhelming percentage of the respondents said that the MBAs hired within the past five years by their organizations knew finance theory but did not have enough basic practice." Advances in technology require that finance graduates possess skills to obtain, evaluate, and analyze real-time information, and use computers as a tool to complete assigned tasks. To better prepare our students for this world of rapid technological innovation, it is vital that business educators take responsibility for the development of students' information technology skills in conjunction with the conventional discipline-specific knowledge and lifelong learning skills. For this reason, finance professors are using various technology tools to improve the education and training of the students. This study focuses on the use of one educational tool, the SAP R/3 system ${ }^{1}$, in finance classrooms. The main purpose of this research is to investigate whether implementing SAP technology in the classroom enhances the student's educational experience. Students' reactions to the use of this business technology in the classroom and their implications for educators are addressed. The findings of this study should be useful to business educators who use, or intend to use, this technology tool in their classes.

\section{The Sap R/3 System}

SAP is currently the world's leading provider of business technology software for all types of industries. Through its R/3 business solution platform, firms around the world are gaining efficiencies throughout their business processes, and maintaining (if not enhancing) the competitive advantages in today's marketplace. It is reported that 
roughly 12 million users from more than 20,000 companies in over 120 countries run more than 64,500 installations of the SAP R/3 system (see SAP Press Release 9/29/03). The implementation of SAP technology in business classrooms has also evolved and expanded significantly with the growth of SAP University Alliance Program in recent years. Being a founding member in the Program, the College of Business at this University has been taking the leadership role in using the SAP R/3 system as an educational tool in its curriculum since August $1996 .{ }^{2}$ SAP Alliance Program has been providing the University with the educational version of its $\mathrm{R} / 3$ system along with all upgrades, technical support and faculty training in a timely manner. SAP R/3 is a comprehensive, integrated business solution system with a proven track record in the real world; it is an excellent tool for teaching students how a business really works. It is considered valuable in the classroom because of the opportunity it provides for mimicking real-life practical scenarios, enabling students to practice finance before they actually enter the highly competitive business world. Specific benefits of incorporating this technology in the classroom include: access to leading edge technology, bridging the gap between theory and practice, enhanced marketability, lifelong learning and research opportunities. While the advantages of integrating the SAP R/3 system in the classroom seem remarkable, little has been reported on the benefits of hands-on experience from students' point of view. This research contributes to the literature by presenting my personal experience on the integration of SAP R/3 technology in finance classrooms and exploring the value of using this educational tool in the classroom from the students' perspective.

\section{Methodology}

Business students at this University are required to take an introductory Management Information System course in which they learn SAP basics before they take any upper-division option classes. Thus, my SAP assignments are structured based upon the assumption that the students have the working knowledge of SAP software $^{3}$. Instead of teaching SAP software, I focus on the application of the software to manage a firm's financial operations in my classes. Two sets of SAP assignments were adopted between August 2000 and May 2003 in my Financial Management classes; one for the undergraduates and another for the graduate students. The objective of the assignments for the undergraduates is to provide knowledge and skills about the basic functions related to the management of capital investments using SAP Investment Management Module. The assignments were assigned right after the coverage of the capital budgeting chapter in class where students learned how to evaluate proposed capital investments and make sound investment decisions. In conventional finance classrooms, the topic of capital budgeting ends with an accept/reject recommendation regarding a proposed capital investment. SAP Investment Management Module is a good tool to link capital budgeting theory to business practice. To learn how the approved capital investment projects are implemented in practice, students were required to perform investment planning, budgeting, settlement, reports and analyses via a simulated business environment in the SAP R/3 system. As for the graduate students, the objective of the assignments is to provide knowledge and skills about the basic functions related to managing cash flows and currency exchange risks in SAP Cash and Treasury Management Modules. Students were exposed to topics such as international finance, working capital management, and financial planning briefly before they worked on the assignments. Crucial to effective cash flow management for a global corporation with accounts payable (accounts receivable) to (from) different countries is an integrated real-time business planning system, e.g., SAP Cash and Treasury Management Modules, among others. To learn how cash budget and financial planning are implemented in practice for a global corporation, students were required to perform money market and foreign exchange transactions, settlements, reports and analyses via a simulated business environment in the SAP $\mathrm{R} / 3$ system. The SAP grade, worth $10 \%$ of the semester grade, is determined based upon each student's written reports detailing the justifications and outcomes of the financial actions taken to achieve the predetermined objectives in the assignments.

Students' responses regarding the design of the SAP assignments and the value of SAP integration in the classrooms were collected through the end of semester questionnaires administered in my upper-division Financial Management classes in Fall 2000, Fall 2001, and Fall 2002, as well as in the graduate level Financial Management class in Spring 2003. These questionnaires focus, in particular, on students' perceptions about whether this technology tool enhanced their educational experience. A detailed list of the survey questionnaires is given in Appendix A for the undergraduates and Appendix B for the graduate students. The actual response rate for the 
undergraduates is $87 \%$ (123 out of 141) compared to $74 \%$ ( 25 out of 34 ) for the graduate students resulting in the final sample of 148 participants (see Table 1).

Table1. The Sample Size and the Response Rate of the Surveys

\begin{tabular}{|l|c|c|c|c|c|}
\hline & \multicolumn{5}{|c|}{ Group } \\
\hline \# Of Students & \multicolumn{5}{|c|}{ Uraduate } \\
\hline & Fall 2000 & Fall 2001 & Fall 2002 & All & Spring 2003 \\
\hline Enrolled in class & 36 & 42 & 63 & 141 & 34 \\
\hline Participated in survey & 29 & 34 & 60 & 123 & 25 \\
\hline Response rate & $81 \%$ & $81 \%$ & $95 \%$ & $87 \%$ & $74 \%$ \\
\hline
\end{tabular}

\section{Survey Results}

Students' assessment of the implementation of SAP technology in finance classrooms is measured using 5point Liker-type scales, anchored by $5=\mathrm{A}$ (strongly agree) and $1=\mathrm{E}$ (strongly disagree). Survey topics, frequency distributions and distribution statistics (mean and standard deviation) of the questionnaire responses are ranked in terms of mean scores in Appendix C for the undergraduates by semester, Panel A of Table 2 for all undergraduates, and Panel B of Table 2 for the graduate students in the sample. A t-test of significance is performed on each topic to compare the mean response scores of the two student groups in Table 3.

In part I of the questionnaire, the students were asked about the design of the SAP assignments. Panel A of Table 3 presents the survey findings on the design of the assignments as rated by the undergraduates in the sample. It is clear from the Table that the majority of the undergraduate participants were not in favor of the design of the assignments. As presented in Panel A of Table 2, of the123 undergraduate respondents, more than 50 felt that SAP assignments were not only demanding (with a mean score of 3.4) but also challenging (with a mean score of 3.3), and that SAP workload was heavy (with a mean score of 3.2). Furthermore, only about 33\% of the undergraduates in the sample (40 out of 123) reported that SAP assignments were well organized (with a mean score of 2.9), $21 \%$ felt that the objectives of SAP assignments were clear (with a mean score of 2.6), and $23 \%$ felt that the assignments were relevant (with a mean score of 2.5). Interestingly, Panel B of Table 2 depicts very different responses from the graduate respondents on the design of the SAP assignments. None of the graduate participants felt that SAP workload was very heavy. In fact, $36 \%$ of the respondents ( 9 out of 25) felt that the magnitude of SAP work was either light or very light. The relatively low standard deviation $(S D=0.9)$ implies relatively strong agreement across the respondents. Panel A of Table 3 shows that the difference in the mean scores regarding the SAP workload between the graduate group and the undergraduate group is negative and statistically significant at the $1 \%$ level of significance (t-statistic $=-2.69$ ). A similar conclusion applies in regard to "SAP assignments are challenging"; the difference in the mean scores between the two groups is negative and significant at the 5\% level (t-statistic $=-2.06$ ). Panel B of Table 2 shows that a much smaller percentage of the graduate respondents, $32 \%$ as compared to $45 \%$ for the undergraduates in the sample, felt that the assignments were challenging (with a mean score of 2.8). In contrast to the undergraduates' responses, the majority of the graduate respondents felt that SAP assignments were well organized (with a mean score of 3.5), that the assignment objectives were clear (with a mean score of 3.4), and that SAP materials were relevant (with a mean score of 3.4), with mean scores of all three being significantly higher than those of the undergraduate responses with t-statistics of 2.46, 2.83, and 4.79, respectively (see Panel B of Table 2 and Panel A of Table 3). Nonetheless, the graduate participants felt that the assignments were somewhat demanding (with a mean score of 3.4) which is consistent with the undergraduates' response. Panel A of Table 3 shows no significant difference in the mean scores between the graduate and the undergraduate participants on this survey topic. 
Table 2. Frequency Distributions and Distribution Statistics Of The Responses By Student Group

\begin{tabular}{|c|c|c|c|c|c|c|c|c|c|}
\hline \multicolumn{10}{|c|}{ Panel A. Undergraduate Students (Fall 2000-Fall 2002) } \\
\hline & \multirow[t]{2}{*}{ Survey Topic } & \multicolumn{6}{|c|}{ Frequency } & \multicolumn{2}{|c|}{ Statistics } \\
\hline & & $\mathbf{A}$ & B & $\mathbf{C}$ & D & $\mathbf{E}$ & $\mathbf{N}$ & MEAN & SD \\
\hline \multirow[t]{2}{*}{$\mathrm{k}$. } & $\begin{array}{l}\text { SAP is an important tool in } \\
\text { managing the business }\end{array}$ & 37 & 39 & 30 & 10 & 6 & 122 & 3.7 & 1.1 \\
\hline & & $30 \%$ & $32 \%$ & $25 \%$ & $8 \%$ & $5 \%$ & $100 \%$ & & \\
\hline \multirow[t]{2}{*}{ i. } & $\begin{array}{l}\text { SAP is an effective tool in managing } \\
\text { planning and budgeting of capital } \\
\text { investments }\end{array}$ & 34 & 33 & 36 & 11 & 7 & 121 & 3.6 & 1.2 \\
\hline & & $28 \%$ & $27 \%$ & $30 \%$ & $9 \%$ & $6 \%$ & $100 \%$ & & \\
\hline \multirow[t]{2}{*}{ h. } & $\begin{array}{l}\text { SAP exposure will enhance my } \\
\text { marketability }\end{array}$ & 33 & 38 & 22 & 10 & 17 & 120 & 3.5 & 1.4 \\
\hline & & $28 \%$ & $32 \%$ & $18 \%$ & $8 \%$ & $14 \%$ & $100 \%$ & & \\
\hline \multirow[t]{2}{*}{ a. } & SAP assignments are demanding & 20 & 37 & 35 & 23 & 5 & 120 & 3.4 & 1.1 \\
\hline & & $17 \%$ & $31 \%$ & $29 \%$ & $19 \%$ & $4 \%$ & $100 \%$ & & \\
\hline \multirow[t]{2}{*}{ e. } & SAP assignments are challenging & 20 & 35 & 37 & 20 & 10 & 122 & 3.3 & 1.2 \\
\hline & & $16 \%$ & $29 \%$ & $30 \%$ & $16 \%$ & $8 \%$ & $100 \%$ & & \\
\hline \multirow[t]{2}{*}{ d. } & Magnitude of SAP work is heavy & 13 & 39 & 41 & 23 & 7 & 123 & 3.2 & 1.1 \\
\hline & & $11 \%$ & $32 \%$ & $33 \%$ & $19 \%$ & $6 \%$ & $100 \%$ & & \\
\hline \multirow[t]{2}{*}{ j. } & $\begin{array}{l}\text { SAP is preferred to EXCEL in } \\
\text { managing planning and } \\
\text { budgeting of capital investments }\end{array}$ & 18 & 26 & 33 & 18 & 27 & 122 & 2.9 & 1.4 \\
\hline & & $15 \%$ & $21 \%$ & $27 \%$ & $15 \%$ & $22 \%$ & $100 \%$ & & \\
\hline \multirow[t]{2}{*}{ g. } & SAP assignments are well organized & 8 & 32 & 38 & 31 & 14 & 123 & 2.9 & 1.1 \\
\hline & & $7 \%$ & $26 \%$ & $31 \%$ & $25 \%$ & $11 \%$ & $100 \%$ & & \\
\hline \multirow[t]{2}{*}{ b. } & SAP assignment objectives are clear & 4 & 22 & 40 & 37 & 20 & 123 & 2.6 & 1.1 \\
\hline & & $3 \%$ & $18 \%$ & $33 \%$ & $30 \%$ & $16 \%$ & $100 \%$ & & \\
\hline \multirow[t]{2}{*}{ c. } & SAP materials are relevant & 2 & 26 & 32 & 31 & 32 & 123 & 2.5 & 1.1 \\
\hline & & $2 \%$ & $21 \%$ & $26 \%$ & $25 \%$ & $26 \%$ & $100 \%$ & & \\
\hline \multirow[t]{3}{*}{ f. } & $\begin{array}{l}\text { SAP assignments enhanced my } \\
\text { understanding of the integrated } \\
\text { business processes }\end{array}$ & 4 & 20 & 25 & 38 & 36 & 123 & 2.3 & 1.2 \\
\hline & & $3 \%$ & $16 \%$ & $20 \%$ & $31 \%$ & $29 \%$ & $100 \%$ & & \\
\hline & Key Question & Yes & No & & & & & & \\
\hline \multirow[t]{2}{*}{1.} & $\begin{array}{l}\text { Are you interested in learning more } \\
\text { about SAP in the classroom? }\end{array}$ & 66 & 57 & & & & 123 & & \\
\hline & & $54 \%$ & $46 \%$ & & & & $100 \%$ & & \\
\hline
\end{tabular}




\begin{tabular}{|c|c|c|c|c|c|c|c|c|c|}
\hline \multicolumn{10}{|c|}{ Panel B. GRADUATE STUDENTS (SPRING 2003) } \\
\hline & \multirow[t]{2}{*}{ Survey Topic } & \multicolumn{6}{|c|}{$\begin{array}{l}\text { Frequency } \\
\end{array}$} & \multicolumn{2}{|c|}{ Statistics } \\
\hline & & $\mathbf{A}$ & $\mathbf{B}$ & $\mathbf{C}$ & $\mathbf{D}$ & $\mathbf{E}$ & $\mathbf{N}$ & MEAN & SD \\
\hline \multirow[t]{2}{*}{ h. } & $\begin{array}{l}\text { SAP exposure will enhance my } \\
\text { marketability }\end{array}$ & 9 & 5 & 8 & 1 & 2 & 25 & 3.7 & 1.2 \\
\hline & & $36 \%$ & $20 \%$ & $32 \%$ & $4 \%$ & $8 \%$ & $100 \%$ & & \\
\hline \multirow[t]{2}{*}{ i. } & $\begin{array}{l}\text { SAP is an effective tool in managing } \\
\text { cash flows }\end{array}$ & 7 & 7 & 7 & 2 & 1 & 24 & 3.7 & 1.1 \\
\hline & & $29 \%$ & $29 \%$ & $29 \%$ & $8 \%$ & $4 \%$ & $100 \%$ & & \\
\hline \multirow[t]{2}{*}{ g. } & SAP assignments are well organized & 4 & 9 & 8 & 3 & 1 & 25 & 3.5 & 1.0 \\
\hline & & $16 \%$ & $36 \%$ & $32 \%$ & $12 \%$ & $4 \%$ & $100 \%$ & & \\
\hline \multirow[t]{2}{*}{ c. } & SAP materials are relevant & 2 & 11 & 8 & 4 & 0 & 25 & 3.4 & 0.9 \\
\hline & & $8 \%$ & $44 \%$ & $32 \%$ & $16 \%$ & $0 \%$ & $100 \%$ & & \\
\hline \multirow[t]{2}{*}{$\mathrm{k}$. } & $\begin{array}{l}\text { SAP is an important tool in } \\
\text { managing the business }\end{array}$ & 6 & 9 & 4 & 2 & 4 & 25 & 3.4 & 1.4 \\
\hline & & $24 \%$ & $36 \%$ & $16 \%$ & $8 \%$ & $16 \%$ & $100 \%$ & & \\
\hline \multirow[t]{2}{*}{ b. } & SAP assignment objectives are clear & 4 & 10 & 4 & 5 & 2 & 25 & 3.4 & 1.2 \\
\hline & & $16 \%$ & $40 \%$ & $16 \%$ & $20 \%$ & $8 \%$ & $100 \%$ & & \\
\hline \multirow[t]{2}{*}{ a. } & SAP assignments are demanding & 4 & 5 & 11 & 2 & 2 & 24 & 3.3 & 1.1 \\
\hline & & $17 \%$ & $21 \%$ & $46 \%$ & $8 \%$ & $8 \%$ & $100 \%$ & & \\
\hline \multirow[t]{2}{*}{ j. } & $\begin{array}{l}\text { SAP is preferred to EXCEL in } \\
\text { managing cash flows }\end{array}$ & 4 & 6 & 8 & 4 & 3 & 25 & 3.2 & 1.2 \\
\hline & & $16 \%$ & $24 \%$ & $32 \%$ & $16 \%$ & $12 \%$ & $100 \%$ & & \\
\hline \multirow[t]{2}{*}{ f. } & $\begin{array}{l}\text { SAP assignments enhanced my } \\
\text { understanding of the integrated } \\
\text { business processes }\end{array}$ & 1 & 7 & 8 & 6 & 3 & 25 & 2.9 & 1.1 \\
\hline & & $4 \%$ & $28 \%$ & $32 \%$ & $24 \%$ & $12 \%$ & $100 \%$ & & \\
\hline \multirow[t]{2}{*}{ e. } & SAP assignments are challenging & 1 & 7 & 6 & 7 & 4 & 25 & 2.8 & 1.2 \\
\hline & & $4 \%$ & $28 \%$ & $24 \%$ & $28 \%$ & $16 \%$ & $100 \%$ & & \\
\hline \multirow[t]{3}{*}{ d. } & Magnitude of SAP work is heavy & 0 & 4 & 12 & 6 & 3 & 25 & 2.7 & 0.9 \\
\hline & & $0 \%$ & $16 \%$ & $48 \%$ & $24 \%$ & $12 \%$ & $100 \%$ & & \\
\hline & Key Question & Yes & No & & & & & & \\
\hline \multirow[t]{2}{*}{1.} & $\begin{array}{l}\text { Are you interested in learning more } \\
\text { about SAP in the classroom? }\end{array}$ & 17 & 8 & & & & 25 & & \\
\hline & & $68 \%$ & $32 \%$ & & & & $100 \%$ & & \\
\hline
\end{tabular}

$\mathrm{A}=$ strongly agree (5 points), $\mathrm{B}=$ agree (4 points), $\mathrm{C}=$ neutral ( 3 points), $\mathrm{D}=$ disagree ( 2 points),

$\mathrm{E}=$ strongly disagree (1 point)

$\mathrm{N}=$ the total number of respondents in each row; row totals are not all equal because not all respondents ranked every topic

MEAN $=$ the average score of students' responses

$\mathrm{SD}=$ the standard deviation of students' responses 
Table3. Comparisons Of The Mean Scores Between The Graduate And The Undergraduate Respondents

\begin{tabular}{|c|c|c|c|c|c|c|c|}
\hline \multirow[b]{2}{*}{ Survey Topic } & \multicolumn{2}{|c|}{ Undergraduate } & \multicolumn{2}{|c|}{ Graduate } & \multirow[b]{2}{*}{ Diff $^{\mathrm{c}}$} & \multirow[b]{2}{*}{ T-Statistics } & \multirow[b]{2}{*}{$\overline{D f^{D}}$} \\
\hline & Mean $^{\mathrm{a}}$ & $\mathbf{S d}^{\mathbf{b}}$ & Mean & Sd & & & \\
\hline \multicolumn{8}{|c|}{ Panel A. Survey Topics on Design of the SAP Assignments } \\
\hline $\begin{array}{l}\text { SAP assignments are } \\
\text { demanding }\end{array}$ & 3.4 & 1.1 & 3.3 & 1.1 & -0.1 & -0.30 & 142 \\
\hline $\begin{array}{l}\text { SAP assignments are } \\
\text { challenging }\end{array}$ & 3.3 & 1.2 & 2.8 & 1.2 & $-0.5 *$ & -2.06 & 145 \\
\hline SAP workload is heavy & 3.2 & 1.1 & 2.7 & 0.9 & $-0.5 * *$ & -2.69 & 146 \\
\hline $\begin{array}{l}\text { SAP assignments are well } \\
\text { organized }\end{array}$ & 2.9 & 1.1 & 3.5 & 1.0 & $0.6 *$ & 2.46 & 146 \\
\hline $\begin{array}{l}\text { SAP assignments objectives are } \\
\text { clear }\end{array}$ & 2.6 & 1.1 & 3.4 & 1.2 & $0.7 * *$ & 2.83 & 146 \\
\hline SAP materials are relevant & 2.5 & 1.1 & 3.4 & 0.9 & $1.0 * * *$ & 4.79 & 146 \\
\hline \multicolumn{8}{|c|}{ Panel B. Survey Topics on the Value of SAP Integration } \\
\hline $\begin{array}{l}\text { SAP is an important tool in } \\
\text { managing the business }\end{array}$ & 3.7 & 1.1 & 3.4 & 1.4 & -0.3 & 1.04 & 145 \\
\hline $\begin{array}{l}\text { SAP is an effective tool in } \\
\text { managing planning and } \\
\text { budgeting of capital } \\
\text { investments (cash flows) }\end{array}$ & 3.6 & 1.2 & 3.7 & 1.1 & na & na & na \\
\hline $\begin{array}{l}\text { SAP exposure will enhance my } \\
\text { marketability }\end{array}$ & 3.5 & 1.4 & 3.7 & 1.2 & 0.2 & 0.79 & 143 \\
\hline $\begin{array}{l}\text { SAP is preferred to EXCEL in } \\
\text { managing planning and } \\
\text { budgeting of capital } \\
\text { investments (cash flows) }\end{array}$ & 2.9 & 1.4 & 3.2 & 1.2 & na & na & na \\
\hline $\begin{array}{l}\text { SAP assignments enhanced my } \\
\text { understanding of the integrated } \\
\text { business processes }\end{array}$ & 2.3 & 1.2 & 2.9 & 1.1 & $0.6 *$ & 2.26 & 146 \\
\hline
\end{tabular}

${ }^{a}$ MEAN = average score of students' responses

${ }^{\mathrm{b}} \mathrm{SD}=$ standard deviation of students' responses

${ }^{\mathrm{c}} \mathrm{DIFF}=$ graduate mean score - undergraduate mean score

$\mathrm{d} \mathrm{df}=$ degrees of freedom

na $=$ not applicable

*Significant at $5 \%$ level

** Significant at $1 \%$ level

$* * *$ Significant at $0.1 \%$ level

Students were also asked about their perceived benefits of using SAP technology in the classroom. Panel B of Table 3 presents the survey results on the value of SAP integration as ranked by the undergraduates. Among the most perceived benefits reported by the undergraduate participants was "SAP is an important tool in managing the business" (with a mean score of 3.7); others included "SAP is an effective tool in managing planning and budgeting of capital investments" (with a mean score of 3.6), and "SAP exposure will enhance my marketability" (with a mean score of 3.5). Panel A of Table 2 reveals that about $62 \%$ of the undergraduate respondents (76 out of 122) either agreed or strongly agreed that "SAP is an important tool in managing the business" while only $13 \%$ either disagreed or strongly disagreed. More than $55 \%$ of the undergraduate respondents ( 67 out of 121$)$ felt that "SAP is an effective 
tool in managing planning and budgeting of capital investments" and only $15 \%$ felt otherwise. Roughly $60 \%$ of the undergraduates in the sample felt that SAP exposure would enhance their marketability and about $22 \%$ didn't feel that way. At the bottom of the value list are "SAP assignments enhanced my understanding of the integrated business processes" (with a mean score of 2.3), and "SAP is preferred to EXCEL in managing planning and budgeting of capital investments" (with a mean score of 2.9). Panel A of Table 2 shows that slightly less than 20\% of the undergraduate participants expressed that their understanding of the integrated business processes was enhanced, while the majority of the undergraduate respondents in the sample either disagreed or strongly disagreed. Furthermore, the undergraduates were split between SAP and EXCEL in managing planning and budgeting of capital investments; $36 \%$ of the undergraduate respondents (44 out of 122) preferred SAP to EXCEL, 37\% (45 out of 122) preferred EXCEL, and the remaining 27\% (33 out of 122) indicated no preference. Not surprisingly, Panel B of Table 2 reveals somewhat different ratings on the value of SAP integration in the classroom by the graduate participants. "SAP exposure will enhance my marketability" (with a mean score of 3.72) is ranked on the top of the value list by the graduate students in the sample with a 56\% approval rating, followed very closely by "SAP is an effective tool in managing cash flows" (with a mean score of 3.71) with a 60\% approval rating. Also, more than onehalf of the graduate students felt that "SAP is an important tool in managing the business" (with a mean score of 3.4). With regards to the preferred tool in managing cash flows, $40 \%$ of the graduate respondents expressed preference for SAP over EXCEL (with a mean score of 3.2) while 28\% preferred EXCEL to SAP, and 32\% were indifferent. Although the graduate students in the sample indicated a greater preference for SAP over EXCEL than did the undergraduate participants, the mean score difference is not statistically significant at any reasonable level of significance on the basis of a t-test reported (see Panel B of Table 3). In addition, 32\% of the graduate students in the sample felt that SAP assignments enhanced their understanding of the integrated business processes (with a mean score of 2.9). This benefit, although ranked at the bottom of the value list, was appreciated more by the graduate students than by the undergraduates in the sample; with the difference in the mean scores between the graduate and the undergraduate groups being positive and statistically significant with t-statistics of 2.26 (see Panel B of Table 3).

Furthermore, the majority of the students in the survey responded affirmatively to the key question at the end of part I of the questionnaire: Are you interested in learning more about SAP in the classroom? Table 2 shows that $54 \%$ of the undergraduate participants (66 out of 123) and 68\% of the graduate respondents (17 out of 25) expressed interest in learning more about SAP technology in class. It is interesting to note that only $38 \%$ of the participants in Fall 2000 responded "Yes" to the key question, but the students' interest level grew to 53\% in Fall 2001 and to 62\% in Fall 2002 (see Appendix C).

Finally, in part II of the questionnaire, students were asked to comment on the PROS and CONS of SAP integration in the classroom. The students' written comments were congruent with the responses in part I of the questionnaire. The comments from the graduate students in the sample included: "It seems that large businesses use SAP (or an equivalent product), therefore using it in more than one MBA courses is helpful to learn the concepts necessary to understand SAP." "The class should be held in the SAP lab where every student sitting in front of the computer terminal." and "If I were an MIS major then SAP would be more valuable to me." As to the undergraduate participants, some of them highlighted the problems associated with the SAP assignments: "Need more help in the Lab; you can get very mad and frustrated over a simple error." "The hardest part was just getting familiar with SAP operations. After that everything was a lot easier." "Need more training in SAP" and "It must be useful if most companies use SAP, however I don't think we went into it enough to make it very beneficial." Others revealed resistance of using SAP technology in the classroom, e.g., "I am sick of the COB pushing SAP down our throats. Most students will never use of program again. I would avoid a job that requires the use of SAP." "One must realize that SAP is a program mostly for large to very large companies, not for someone who will be starting one's business." "Leave SAP to MIS guys." Nevertheless, some positive comments from the undergraduate participants emerged: "I believe SAP is an incredible tool for companies." "It's a hard trade between SAP and an extra chapter in Brigham. SAP was challenging and I enjoyed it." and "The SAP assignments were good in showing how ERP (enterprise resource planning) is used in financial management." 


\section{Discussion}

Due to a relatively small sample of students participated in this study; generalizations to the population must be used with caution. Overall, it is encouraging to find the favorable feedback from the graduate students in the sample regarding the integration of SAP in the classroom. Although the graduate participants felt that the SAP assignments were somewhat demanding, they had no problems in completing the assignments. It appears that they were motivated to use the technology in the classroom, and recognized the benefits of using it. The most perceived benefit, the enhanced marketability, is the driving force for the graduate students in the sample. On the other hand, a great number of undergraduates in the sample were frustrated with the workload of the SAP assignments, and failed to see the relevance and value of doing them. Even though the majority of undergraduates in the sample felt that "SAP is an important tool in managing the business," and that "SAP is an effective tool in managing planning and budgeting of capital investments," no strong preference for SAP over EXCEL in managing planning and budgeting of capital investments was reported in the questionnaire. Clearly, the undergraduate respondents' disapproval of the design of the assignments and value of SAP technology can be a major obstacle to successfully implementing the technology in the classrooms and can result in unfavorable ratings of teaching effectiveness. To reduce the students' resistance to using SAP technology in the classrooms and to enhance their learning experience, it may be necessary to scale down the assignments and provide more guidance/directions in the assignments. It is not recommended, however, to increase the weighting of SAP grade from the current $10 \%$ level since the primary focus of the course is still on financial theory and concepts. One might wonder: Is it worthwhile to integrate the SAP technology in the classroom? The answer is: Definitely! Because it is very important that finance students learn how to apply finance theory to make practical financial decisions via a simulated business environment. The SAP technology offers such a learning opportunity, because it introduces real life business scenarios into the classroom, shows students the problems that they will encounter when they actually enter the workplace, and allows students to develop and improve the skills required for day-to-day operations.

\section{Summary and Conclusion}

The findings in this study indicate that the graduate students in the sample responded much more favorably to the integration of SAP technology in finance classrooms as did the undergraduate participants. On the design of the SAP assignments, the graduate respondents felt that the assignments were well organized, the objectives were clear, the workload was light, and the materials were relevant, while the undergraduate participants felt otherwise. Also, a greater percentage of the undergraduates in the sample felt challenged by the SAP assignments than did the graduate participants. Nonetheless, both groups of students felt that the assignments were somewhat demanding. On the benefits of using SAP technology in the classrooms, the consensus from both the graduate and undergraduate students in the sample is that "SAP is an important tool in managing the business," "SAP is an effective tool in managing planning and budgeting of capital investments (cash flows)," and "SAP exposure will enhance my marketability". Moreover, the graduate respondents appreciated how SAP assignments enhanced their understanding of the integrated business processes much more than did the undergraduate students in the sample. Nevertheless, no significant difference between the mean scores regarding the preference for SAP over EXCEL is observed from either group of participants, although a greater percentage of the graduate respondents preferred SAP as compared to the undergraduate respondents. Finally, it is interesting to note that the students' interest in learning more about SAP technology has been increasing steadily over the semesters in the survey.

To conclude, the SAP R/3 system is valuable in the classroom because of the opportunity it provides for mimicking real-life practical scenarios, enabling students to practice finance before they actually work in this highly competitive business world. Nevertheless, it is crucial that students (especially the undergraduates) be sold on the idea of using the advanced business technology for the SAP R/3 approach to be effective in the classroom. Integration of current technology in the classroom requires more effort from both the students and the instructor than does the traditional lecture method. To be successful in integrating the technology in the classroom, not only the instructor must be at the forefront of the business technology and be interested in the challenges of using it, but also the students must be open-minded and willing to work hard in the course. Integrating the technology in the classroom benefits not only the students but the instructor as well; the students with SAP R/3 experience are highly 
favored by business recruiters in today's job market, and the instructor involved with SAP implementation has the opportunity to stay current in the cutting-edge business technology as well as to pursue more research areas.

\section{Endnotes}

1. SAP is the company, R/3 is the product and R stands for real time; SAP R/3 stands for Systems, Applications and Products in Data Processing.

2. SAP R/3 system has been implemented in accounting, finance, management information system, production \& operations management, and marketing courses at this College of Business.

3. Competent SAP lab assistants were available to help students with the use of the software during the lab open hours throughout the semester. In addition, some SAP demo exercises relevant to the assignments were made available to students at the beginning of the semester.

\section{References}

1. Baker, H. K. and A. L. Phillips, "Career Paths of Corporate CFOs and Treasures" Financial Practice and Education, Fall/Winter 1999, Vol. 9(2): 38-50.

2. McCorkle, D. E., J. F. Alexander, and J. Reardon, "Integrating Business Technology and Marketing Education: Enhancing the Diffusion Process through Technology Champions" Journal of Marketing Education, April 2001, Vol. 23(1): 16-24.

3. Paul, P. and K. Mukhopadhyay, "Using Information Technology for Active Learning in International Business Education" Marketing Education Review, fall 2001, Vol. 11(3): 81-89.

4. Pendegraft, N., R. W. Stone, and C. R. Byers, "Using Information Systems as a Unifying Influence I an Integrated Business Curriculum" Journal of Information System Education, 1999, Vol. 11(1/2): 61-66.

5. SAP, AG. "SAP Charts the Course for Tomorrow's Business Innovations" Press Release September 29, 2003, http://www.sap.com/company/press/press.asp?pressID=2436

6. Selen, W. "Learning in the New Business School Setting: A Collaborative Model" The Learning Organization, 2001, Vol. 8(3/4): 106-114.

7. Shoemaker, M. E. "What Marketing Students Need to Know about Enterprise Resource Planning (ERP) Systems" Marketing Education Review, summer 2003, Vol. 13(2): 69-77.

8. Ueltschy, L. C. "An Exploratory Study of Integrating Interactive Technology into the Marketing Curriculum" Journal of Marketing Education, April 2001, Vol. 23(1): 63-72. 


\section{Appendixes}

\section{Appendix A. Questionnaire On Sap Implementation For Undergraduates}

I. Circle the letter on the scale which best describes your feelings about the SAP implementation in FINANCE 155: Financial Management. Please indicate only one letter for each set.

\begin{tabular}{|c|c|c|c|c|c|c|c|}
\hline a. & $\begin{array}{l}\text { SAP assignment } \\
\text { extremely demanding }\end{array}$ & A & B & $\mathrm{C}$ & $\mathrm{D}$ & $\mathrm{E}$ & SAP assignment not demanding \\
\hline b. & $\begin{array}{l}\text { SAP assignment } \\
\text { objectives clear }\end{array}$ & A & B & $\mathrm{C}$ & $\mathrm{D}$ & $\mathrm{E}$ & SAP assignment objectives unclear \\
\hline c. & $\begin{array}{l}\text { SAP materials very } \\
\text { relevant }\end{array}$ & A & B & $\mathrm{C}$ & $\mathrm{D}$ & $\mathrm{E}$ & SAP materials irrelevant \\
\hline d. & $\begin{array}{l}\text { Magnitude of SAP work } \\
\text { very heavy }\end{array}$ & A & B & $\mathrm{C}$ & $\mathrm{D}$ & $\mathrm{E}$ & Magnitude of SAP work very light \\
\hline e. & $\begin{array}{l}\text { SAP materials very } \\
\text { challenging }\end{array}$ & $\bar{A}$ & B & $\mathrm{C}$ & $\mathrm{D}$ & $\mathrm{E}$ & SAP materials not challenging \\
\hline f. & $\begin{array}{l}\text { SAP materials enhanced } \\
\text { my understanding of the } \\
\text { integrated business } \\
\text { processes }\end{array}$ & A & B & $\mathrm{C}$ & $\mathrm{D}$ & $\mathrm{E}$ & $\begin{array}{l}\text { SAP materials did not enhance my } \\
\text { understanding of the integrated business } \\
\text { processes }\end{array}$ \\
\hline g. & $\begin{array}{l}\text { SAP assignment well } \\
\text { organized }\end{array}$ & $\bar{A}$ & B & $\mathrm{C}$ & $\mathrm{D}$ & $\mathrm{E}$ & SAP assignment poorly organized \\
\hline h. & $\begin{array}{l}\text { SAP exposure will } \\
\text { enhance my marketability }\end{array}$ & A & B & $\mathrm{C}$ & $\mathrm{D}$ & $\mathrm{E}$ & $\begin{array}{l}\text { SAP exposure won't enhance my } \\
\text { marketability }\end{array}$ \\
\hline i. & $\begin{array}{l}\text { SAP is an effective tool in } \\
\text { managing planning and } \\
\text { budgeting of capital } \\
\text { investments }\end{array}$ & A & B & $\mathrm{C}$ & $\mathrm{D}$ & $\mathrm{E}$ & $\begin{array}{l}\text { SAP is not an effective tool in managing } \\
\text { planning and budgeting of capital } \\
\text { investments }\end{array}$ \\
\hline j. & $\begin{array}{l}\text { SAP is preferred to } \\
\text { EXCEL in managing } \\
\text { planning } \\
\text { and budgeting of capital } \\
\text { investments }\end{array}$ & A & B & $\mathrm{C}$ & $\mathrm{D}$ & $\mathrm{E}$ & $\begin{array}{l}\text { EXCEL is preferred to SAP in managing } \\
\text { planning and budgeting of capital } \\
\text { investments }\end{array}$ \\
\hline $\mathrm{k}$. & $\begin{array}{l}\text { SAP is an important tool } \\
\text { in managing the business }\end{array}$ & $\bar{A}$ & B & $\mathrm{C}$ & $\mathrm{D}$ & $\mathrm{E}$ & $\begin{array}{l}\text { SAP is not an important tool in managing } \\
\text { the business }\end{array}$ \\
\hline 1. & $\begin{array}{l}\text { Are you interested in } \\
\text { learning more about SAP } \\
\text { in the classroom? }\end{array}$ & & & & & & $\begin{array}{l}\text { YES } \\
\text { NO }\end{array}$ \\
\hline
\end{tabular}

II. Please feel free to write your comments regarding SAP implementation in the classroom on the back. PROS and CONS ...

THANK YOU FOR YOUR INPUT! 


\section{Appendix B. Questionnaire On Sap Implementation For Graduate Students}

I. Circle the letter on the scale that best describes your feelings about the SAP implementation in FINANCE 355: Seminar in Financial Management. Please indicate only one letter for each set.

\begin{tabular}{|c|c|c|c|c|c|c|c|}
\hline a. & $\begin{array}{l}\text { SAP assignment } \\
\text { extremely demanding }\end{array}$ & $\mathrm{A}$ & B & $\mathrm{C}$ & $\mathrm{D}$ & $\mathrm{E}$ & SAP assignment not demanding \\
\hline b. & $\begin{array}{l}\text { SAP assignment } \\
\text { objectives clear }\end{array}$ & A & $B$ & $\mathrm{C}$ & $\mathrm{D}$ & $\mathrm{E}$ & SAP assignment objectives unclear \\
\hline c. & $\begin{array}{l}\text { SAP materials very } \\
\text { relevant }\end{array}$ & $\overline{\mathrm{A}}$ & B & $\mathrm{C}$ & $\mathrm{D}$ & $\mathrm{E}$ & SAP materials irrelevant \\
\hline d. & $\begin{array}{l}\text { Magnitude of SAP work } \\
\text { very heavy }\end{array}$ & $\mathrm{A}$ & B & $\mathrm{C}$ & D & $E$ & Magnitude of SAP work very light \\
\hline e. & $\begin{array}{l}\text { SAP materials very } \\
\text { challenging }\end{array}$ & A & $\mathrm{B}$ & $\mathrm{C}$ & $\mathrm{D}$ & $E$ & SAP materials not challenging \\
\hline f. & $\begin{array}{l}\text { SAP materials enhanced } \\
\text { my understanding of the } \\
\text { integrated business } \\
\text { processes }\end{array}$ & $\mathrm{A}$ & B & $\mathrm{C}$ & $\mathrm{D}$ & $E$ & $\begin{array}{l}\text { SAP materials did not enhance my } \\
\text { understanding of the integrated business } \\
\text { processes }\end{array}$ \\
\hline g. & $\begin{array}{l}\text { SAP assignment well } \\
\text { organized }\end{array}$ & A & $B$ & $\mathrm{C}$ & $\mathrm{D}$ & $E$ & SAP assignment poorly organized \\
\hline h. & $\begin{array}{l}\text { SAP exposure will } \\
\text { enhance my marketability }\end{array}$ & $\mathrm{A}$ & B & C & D & $E$ & $\begin{array}{l}\text { SAP exposure won't enhance my } \\
\text { marketability }\end{array}$ \\
\hline i. & $\begin{array}{l}\text { SAP is an effective tool in } \\
\text { managing cash flows }\end{array}$ & A & B & $\mathrm{C}$ & $\mathrm{D}$ & $\mathrm{E}$ & $\begin{array}{l}\text { SAP is not an effective tool in managing } \\
\text { cash flows }\end{array}$ \\
\hline j. & $\begin{array}{l}\text { SAP is preferred to } \\
\text { EXCEL in managing cash } \\
\text { flows }\end{array}$ & A & $\mathrm{B}$ & $\mathrm{C}$ & $\mathrm{D}$ & $\mathrm{E}$ & $\begin{array}{l}\text { EXCEL is preferred to SAP in managing } \\
\text { cash flows }\end{array}$ \\
\hline $\mathrm{k}$. & $\begin{array}{l}\text { SAP is an important tool } \\
\text { in managing the business }\end{array}$ & A & $\mathrm{B}$ & $\mathrm{C}$ & $\mathrm{D}$ & & $\begin{array}{l}\text { SAP is not an important tool in managing } \\
\text { the business }\end{array}$ \\
\hline 1. & $\begin{array}{l}\text { Are you interested in } \\
\text { learning more about SAP } \\
\text { in the classroom? }\end{array}$ & & & & & & $\begin{array}{l}\text { YES } \\
\text { NO }\end{array}$ \\
\hline
\end{tabular}

II. Please feel free to write your comments regarding SAP implementation in the classroom on the back. PROS and CONS ...

THANK YOU FOR YOUR INPUT! 
Appendix C. Frequency Distributions And Distribution Statistics Of The Undergraduates' Responses By Semester

\begin{tabular}{|c|c|c|c|c|c|c|c|c|c|}
\hline & & & el A. & LLL 2 & & & & & \\
\hline & Survey Topic & & & Fre & ency & & & & \\
\hline & & $\mathbf{A}$ & $\mathbf{B}$ & $\mathbf{C}$ & D & $\mathbf{E}$ & $\mathbf{N}$ & MEAN & SD \\
\hline $\mathrm{k}$. & $\begin{array}{l}\text { SAP is an important tool in } \\
\text { managing the business }\end{array}$ & 6 & 7 & 7 & 5 & 3 & 28 & 3.3 & 1.3 \\
\hline & & $21 \%$ & $25 \%$ & $25 \%$ & $18 \%$ & $11 \%$ & $100 \%$ & & \\
\hline a. & SAP assignments are demanding & 4 & 6 & 8 & 8 & 2 & 28 & 3.1 & 1.2 \\
\hline & & $14 \%$ & $21 \%$ & $29 \%$ & $29 \%$ & $7 \%$ & $100 \%$ & & \\
\hline d. & Magnitude of SAP work is heavy & 4 & 4 & 13 & 5 & 3 & 29 & 3.0 & 1.1 \\
\hline & & $14 \%$ & $14 \%$ & $45 \%$ & $17 \%$ & $10 \%$ & $100 \%$ & & \\
\hline e. & SAP assignments are challenging & 2 & 8 & 7 & 8 & 3 & 28 & 2.9 & 1.2 \\
\hline & & $7 \%$ & $29 \%$ & $25 \%$ & $29 \%$ & $11 \%$ & $100 \%$ & & \\
\hline i. & $\begin{array}{l}\text { SAP is an effective tool in } \\
\text { managing planning and } \\
\text { budgeting of capital investments }\end{array}$ & 3 & 5 & 12 & 3 & 6 & 29 & 2.9 & 1.2 \\
\hline & & $10 \%$ & $17 \%$ & $41 \%$ & $10 \%$ & $21 \%$ & $100 \%$ & & \\
\hline h. & $\begin{array}{l}\text { SAP exposure will enhance my } \\
\text { marketability }\end{array}$ & 2 & 7 & 5 & 7 & 6 & 27 & 2.7 & 1.3 \\
\hline & & $7 \%$ & $26 \%$ & $19 \%$ & $26 \%$ & $22 \%$ & $100 \%$ & & \\
\hline b. & $\begin{array}{l}\text { SAP assignment objectives are } \\
\text { clear }\end{array}$ & 1 & 3 & 11 & 11 & 3 & 29 & 2.6 & 0.9 \\
\hline & & $3 \%$ & $10 \%$ & $38 \%$ & $38 \%$ & $10 \%$ & $100 \%$ & & \\
\hline g. & $\begin{array}{l}\text { SAP assignments are well } \\
\text { organized }\end{array}$ & 1 & 5 & 6 & 15 & 2 & 29 & 2.6 & 1.0 \\
\hline & & $3 \%$ & $17 \%$ & $21 \%$ & $52 \%$ & $7 \%$ & $100 \%$ & & \\
\hline $\mathrm{j}$. & $\begin{array}{l}\text { SAP is preferred to EXCEL in } \\
\text { managing planning and } \\
\text { budgeting of capital investments }\end{array}$ & 2 & 6 & 5 & 7 & 9 & 29 & 2.5 & 1.3 \\
\hline & & $7 \%$ & $21 \%$ & $17 \%$ & $24 \%$ & $31 \%$ & $100 \%$ & & \\
\hline c. & SAP materials are relevant & 0 & 3 & 6 & 8 & 12 & 29 & 2.0 & 1.0 \\
\hline & & $0 \%$ & $10 \%$ & $21 \%$ & $28 \%$ & $41 \%$ & $100 \%$ & & \\
\hline f. & $\begin{array}{l}\text { SAP assignments enhanced my } \\
\text { understanding of the integrated } \\
\text { business processes }\end{array}$ & 0 & 3 & 4 & 9 & 13 & 29 & 1.9 & 1.0 \\
\hline & & $0 \%$ & $10 \%$ & $14 \%$ & $31 \%$ & $45 \%$ & $100 \%$ & & \\
\hline & KEY QUESTION & YES & NO & & & & & & \\
\hline 1. & $\begin{array}{l}\text { Are you interested in learning } \\
\text { more about SAP in the } \\
\text { classroom? }\end{array}$ & 11 & 18 & & & & 29 & & \\
\hline & & $38 \%$ & $62 \%$ & & & & $100 \%$ & & \\
\hline
\end{tabular}




\begin{tabular}{|c|c|c|c|c|c|c|c|c|c|}
\hline \multicolumn{10}{|c|}{ Panel B. FALL 2001 } \\
\hline & Survey Topic & \multicolumn{6}{|c|}{ Frequency } & \multicolumn{2}{|c|}{ Statistics } \\
\hline & & A & B & $\mathbf{C}$ & D & $\mathbf{E}$ & $\mathbf{N}$ & MEAN & SD \\
\hline \multirow[t]{2}{*}{ e. } & SAP assignments are challenging & 8 & 15 & 9 & 2 & 0 & 34 & 3.9 & 0.9 \\
\hline & & $24 \%$ & $44 \%$ & $26 \%$ & $6 \%$ & $0 \%$ & $100 \%$ & & \\
\hline \multirow[t]{2}{*}{ i. } & $\begin{array}{l}\text { SAP is an effective tool in } \\
\text { managing planning and } \\
\text { budgeting of capital investments }\end{array}$ & 12 & 6 & 11 & 5 & 0 & 34 & 3.7 & 1.1 \\
\hline & & $35 \%$ & $18 \%$ & $32 \%$ & $15 \%$ & $0 \%$ & $100 \%$ & & \\
\hline \multirow[t]{2}{*}{$\mathrm{k}$. } & $\begin{array}{l}\text { SAP is an important tool in } \\
\text { managing the business }\end{array}$ & 10 & 11 & 7 & 5 & 1 & 34 & 3.7 & 1.1 \\
\hline & & $29 \%$ & $32 \%$ & $21 \%$ & $15 \%$ & $3 \%$ & $100 \%$ & & \\
\hline \multirow[t]{2}{*}{ a. } & SAP assignments are demanding & 6 & 11 & 13 & 4 & 0 & 34 & 3.6 & 0.9 \\
\hline & & $18 \%$ & $32 \%$ & $38 \%$ & $12 \%$ & $0 \%$ & $100 \%$ & & \\
\hline \multirow[t]{2}{*}{ d. } & Magnitude of SAP work is heavy & 5 & 13 & 8 & 7 & 1 & 34 & 3.4 & 1.1 \\
\hline & & $15 \%$ & $38 \%$ & $24 \%$ & $21 \%$ & $3 \%$ & $100 \%$ & & \\
\hline \multirow[t]{2}{*}{ h. } & $\begin{array}{l}\text { SAP exposure will enhance my } \\
\text { marketability }\end{array}$ & 11 & 10 & 4 & 0 & 9 & 34 & 3.4 & 1.6 \\
\hline & & $32 \%$ & $29 \%$ & $12 \%$ & $0 \%$ & $26 \%$ & $100 \%$ & & \\
\hline \multirow[t]{2}{*}{ g. } & $\begin{array}{l}\text { SAP assignments are well } \\
\text { organized }\end{array}$ & 1 & 13 & 8 & 7 & 5 & 34 & 2.9 & 1.2 \\
\hline & & $3 \%$ & $38 \%$ & $24 \%$ & $21 \%$ & $15 \%$ & $100 \%$ & & \\
\hline \multirow[t]{2}{*}{ j. } & $\begin{array}{l}\text { SAP is preferred to EXCEL in } \\
\text { managing planning and } \\
\text { budgeting of capital investments }\end{array}$ & 5 & 8 & 9 & 3 & 9 & 34 & 2.9 & 1.4 \\
\hline & & $15 \%$ & $24 \%$ & $26 \%$ & $9 \%$ & $26 \%$ & $100 \%$ & & \\
\hline \multirow[t]{2}{*}{ c. } & SAP materials are relevant & 0 & 12 & 10 & 6 & 6 & 34 & 2.8 & 1.1 \\
\hline & & $0 \%$ & $35 \%$ & $29 \%$ & $18 \%$ & $18 \%$ & $100 \%$ & & \\
\hline \multirow[t]{2}{*}{ b. } & $\begin{array}{l}\text { SAP assignment objectives are } \\
\text { clear }\end{array}$ & 2 & 7 & 9 & 9 & 7 & 34 & 2.6 & 1.2 \\
\hline & & $6 \%$ & $21 \%$ & $26 \%$ & $26 \%$ & $21 \%$ & $100 \%$ & & \\
\hline \multirow[t]{3}{*}{ f. } & $\begin{array}{l}\text { SAP assignments enhanced my } \\
\text { understanding of the integrated } \\
\text { business processes }\end{array}$ & 3 & 8 & 1 & 13 & 9 & 34 & 2.5 & 1.4 \\
\hline & & $9 \%$ & $24 \%$ & $3 \%$ & $38 \%$ & $26 \%$ & $100 \%$ & & \\
\hline & KEY QUESTION & YES & NO & & & & & & \\
\hline \multirow[t]{2}{*}{1.} & $\begin{array}{l}\text { Are you interested in learning } \\
\text { more about SAP in the } \\
\text { classroom? }\end{array}$ & 18 & 16 & & & & 34 & & \\
\hline & & $53 \%$ & $47 \%$ & & & & $100 \%$ & & \\
\hline
\end{tabular}




\begin{tabular}{|c|c|c|c|c|c|c|c|c|c|}
\hline \multicolumn{10}{|c|}{ Panel C. FALL 2002} \\
\hline & Survey Topic & \multicolumn{6}{|c|}{ Frequency } & \multicolumn{2}{|c|}{ Statistics } \\
\hline & & $\mathbf{A}$ & $\mathbf{B}$ & $\mathbf{C}$ & D & $\mathbf{E}$ & $\mathbf{N}$ & MEAN & SD \\
\hline \multirow[t]{2}{*}{$\mathrm{k}$} & $\begin{array}{l}\text { SAP is an important tool in } \\
\text { managing the business }\end{array}$ & 21 & 21 & 16 & 0 & 2 & 60 & 4.0 & 1.0 \\
\hline & & $35 \%$ & $35 \%$ & $27 \%$ & $0 \%$ & $3 \%$ & $100 \%$ & & \\
\hline \multirow[t]{2}{*}{ i. } & $\begin{array}{l}\text { SAP is an effective tool in } \\
\text { managing planning and } \\
\text { budgeting of capital investments }\end{array}$ & 19 & 22 & 13 & 3 & 1 & 58 & 3.9 & 1.0 \\
\hline & & $33 \%$ & $38 \%$ & $22 \%$ & $5 \%$ & $2 \%$ & $100 \%$ & & \\
\hline \multirow[t]{2}{*}{ h. } & $\begin{array}{l}\text { SAP exposure will enhance my } \\
\text { marketability }\end{array}$ & 20 & 21 & 13 & 3 & 2 & 59 & 3.9 & 1.0 \\
\hline & & $34 \%$ & $36 \%$ & $22 \%$ & $5 \%$ & $3 \%$ & $100 \%$ & & \\
\hline \multirow[t]{2}{*}{ a. } & SAP assignments are demanding & 10 & 20 & 14 & 11 & 3 & 58 & 3.4 & 1.1 \\
\hline & & $17 \%$ & $34 \%$ & $24 \%$ & $19 \%$ & $5 \%$ & $100 \%$ & & \\
\hline \multirow[t]{2}{*}{ d. } & Magnitude of SAP work is heavy & 4 & 22 & 20 & 11 & 3 & 60 & 3.2 & 1.0 \\
\hline & & $7 \%$ & $37 \%$ & $33 \%$ & $18 \%$ & $5 \%$ & $100 \%$ & & \\
\hline \multirow[t]{2}{*}{ j. } & $\begin{array}{l}\text { SAP is preferred to EXCEL in } \\
\text { managing planning and } \\
\text { budgeting of capital investments }\end{array}$ & 11 & 12 & 19 & 8 & 9 & 59 & 3.1 & 1.3 \\
\hline & & $19 \%$ & $20 \%$ & $32 \%$ & $14 \%$ & $15 \%$ & $100 \%$ & & \\
\hline \multirow[t]{2}{*}{ e. } & SAP assignments are challenging & 10 & 12 & 21 & 10 & 7 & 60 & 3.1 & 1.2 \\
\hline & & $17 \%$ & $20 \%$ & $35 \%$ & $17 \%$ & $12 \%$ & $100 \%$ & & \\
\hline \multirow[t]{2}{*}{ g. } & $\begin{array}{l}\text { SAP assignments are well } \\
\text { organized }\end{array}$ & 6 & 14 & 24 & 9 & 7 & 60 & 3.1 & 1.1 \\
\hline & & $10 \%$ & $23 \%$ & $40 \%$ & $15 \%$ & $12 \%$ & $100 \%$ & & \\
\hline \multirow[t]{2}{*}{ b. } & $\begin{array}{l}\text { SAP assignment objectives are } \\
\text { clear }\end{array}$ & 1 & 12 & 20 & 17 & 10 & 60 & 2.6 & 1.0 \\
\hline & & $2 \%$ & $20 \%$ & $33 \%$ & $28 \%$ & $17 \%$ & $100 \%$ & & \\
\hline \multirow[t]{2}{*}{ c. } & SAP materials are relevant & 2 & 11 & 16 & 17 & 14 & 60 & 2.5 & 1.1 \\
\hline & & $3 \%$ & $18 \%$ & $27 \%$ & $28 \%$ & $23 \%$ & $100 \%$ & & \\
\hline \multirow[t]{3}{*}{ f. } & $\begin{array}{l}\text { SAP assignments enhanced my } \\
\text { understanding of the integrated } \\
\text { business processes }\end{array}$ & 1 & 9 & 20 & 16 & 14 & 60 & 2.5 & 1.1 \\
\hline & & $2 \%$ & $15 \%$ & $33 \%$ & $27 \%$ & $23 \%$ & $100 \%$ & & \\
\hline & KEY QUESTION & YES & NO & & & & & & \\
\hline \multirow[t]{2}{*}{1.} & $\begin{array}{l}\text { Are you interested in learning } \\
\text { more about SAP in the } \\
\text { classroom? }\end{array}$ & 37 & 23 & & & & 60 & & \\
\hline & & $62 \%$ & $38 \%$ & & & & $100 \%$ & & \\
\hline
\end{tabular}

